\title{
Gene Expression and Premature Progesterone Rise
}

\author{
Inge Van Vaerenbergh ${ }^{1}$ and Christophe Blockeel $^{2}$ \\ ${ }^{1}$ Department of Pathology, UZ Brussel and Reproductive Immunology and \\ Implantation (REIM), Vrije Universiteit Brussel, Jette, \\ ${ }^{2}$ Centre for Reproductive Medicine, UZ Brussel / Vrije Universiteit Brussel, Jette, \\ Belgium
}

\section{Introduction}

In present stimulation protocols for IVF, some patients experience a rise in serum progesterone $(\mathrm{P})$ concentration in the late follicular phase. Premature $\mathrm{P}$ rise affects about 5 to as high as $38 \%$ of IVF patients (Edelstein et al., 1990; Silverberg et al., 1991; Ubaldi et al., 1996; Bosch et al., 2003) and is associated with lower implantation and pregnancy rates. It is defined as a rise in $\mathrm{P}$ concentration towards the end of the follicular phase above a certain threshold, which is set arbitrarily. There is an ongoing debate about the definition of premature luteinisation, or better defined as 'premature progesterone rise', as to which threshold for premature P rise should be established (Van Vaerenbergh et al., 2011; Labarta et al., 2011). Therefore, the changes in gene expression were studied in patients with premature progesterone rise.

\section{Research methods}

\subsection{Patients}

This study was approved by the Ethics Committee of the University Hospital of the Vrije Universiteit Brussel. All patients signed an informed consent. The patients included in the study were women below 37 years of age who underwent a first or second treatment cycle of in-vitro fertilisation (IVF) with intracytoplasmic sperm injection (ICSI). Patients were excluded from the study if they requested preimplantation genetic diagnosis, had an azoospermic partner or had a serum follicle-stimulating hormone (FSH) level on day 3 of the menstrual cycle of more than $12 \mathrm{IU} / \mathrm{L}$. A single embryo transfer policy was applied in all cycles. Patients with endometriosis $\geq$ stage III (AFS (American Fertility Society) classification), with PCOS (polycystic ovary syndrome; defined according to the Rotterdam 2003 criteria, Rotterdam ESHRE/ASRM-Sponsored PCOS Consensus Workshop Group, 2004) or with any other endometrial pathology were excluded from the study.

\subsection{Stimulation protocol}

Ovarian stimulation was performed with a median starting dose of $200 \mathrm{IU}$ rec-FSH (follicle stimulating hormone, Puregon ${ }$, MSD, Oss, The Netherlands), from day 2 until day 6 of the 
cycle. From day 7 onwards, the dose was adjusted individually. To inhibit premature LH surge, daily GnRH-antagonist (Orgalutran ${ }^{\circledR} 0,25 \mathrm{mg}$, MSD) was used from the morning of day 6 of stimulation. Final oocyte maturation was achieved by administration of 10000 IU of hCG (human chorionic gonadotrophin, Pregnyl ${ }^{\text {, }, ~ M S D) ~ a s ~ s o o n ~ a s ~} 3$ (or more) follicles $\geq 17$ $\mathrm{mm}$ were present. Oocyte retrieval was carried out 36 hours after hCG administration. The luteal phase was supported with $600 \mathrm{mg}$ micronized progesterone (Utrogestan ${ }^{\circledR}$, Piette, Brussels, Belgium) (Figure 1). IVF and ICSI procedures have been described in detail elsewhere (Van Landuyt et al., 2005).

Freshly ejaculated sperm was used. One or two embryos were transferred in the same cycle on day 3 or day 5 of embryo culture, according to the Belgian reimbursement law. Embryo quality was comparable between patients.

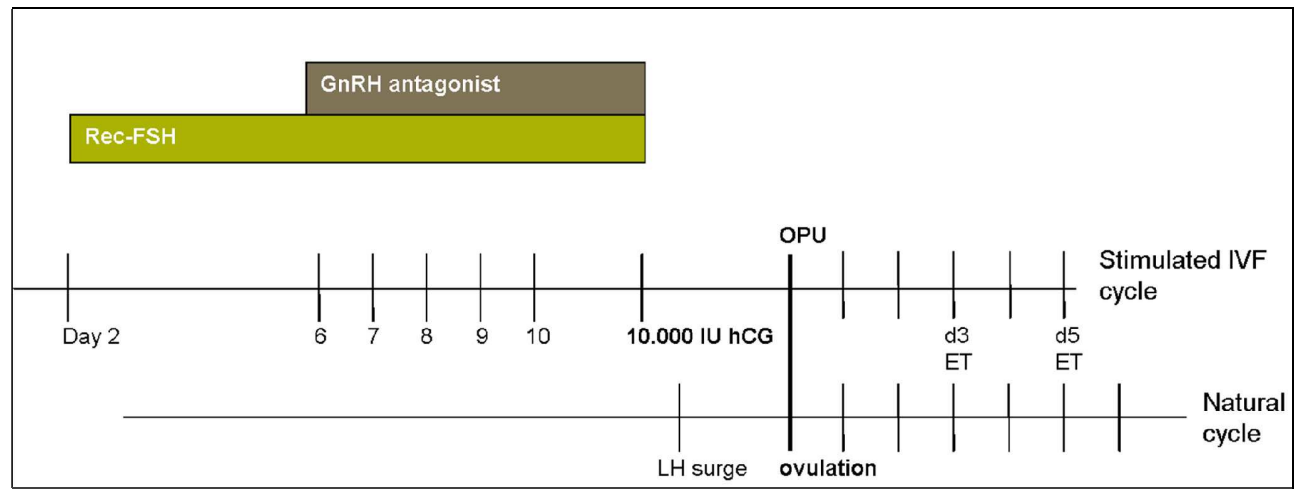

ET: embryo transfer, OPU: oocyte pick-up or oocyte retrieval.

Fig. 1. Stimulation protocol in a GnRH antagonist/rec-FSH IVF cycle. The day of oocyte retrieval in a stimulated cycle is analogous to the day of ovulation in a natural cycle.

\subsection{Human uterine tissue collection}

Endometrial biopsies were taken with a pipelle (Pipelle de Cornier®, Prodimed, Neuilly-enThelle, France) under sterile conditions on the day of oocyte retrieval. The biopsies were divided into two parts. One part of the endometrial tissue was used for classical histological analysis with haematoxylin and eosin staining. Endometrial dating was performed on all samples according to the criteria of Noyes (Noyes et al., 1950) by a pathologist, blinded for clinical outcome. The other part was snap-frozen in liquid nitrogen under sterile conditions for further RNA isolation and gene expression analysis with microarray technology, followed by validation with a more quantitative PCR.

\subsection{Gene expression profiling}

RNA extraction was performed using the RNeasy Mini kit (Qiagen, Valencia, CA, USA). Total RNA concentration was measured with the NanoDrop ND-1000 spectrophotometer (NanoDrop Technologies, Wilmington, DE, USA) and integrity of the RNA samples was controlled using the Agilent 2100 Bioanalyzer with the RNA 6000 Nano Kit (Agilent Technologies Inc., Palo Alto, CA, USA). 
The human genome encodes for approximately 25000 genes, however only a subset is active or expressed in any cell and the levels and timing of RNA expression regulate cellular development, differentiation and function. Microarrays are a tool to make a snapshot of the gene expression situation in a cell or tissue at a particular moment.

For the gene expression analysis, $2 \mu \mathrm{g}$ of the total amount of isolated RNA was reverse transcribed with the SuperScript Choice System (Invitrogen, Carlsbad, CA, USA) with oligodT primers containing a T7 RNA polymerase promotor site (Figure 2). Then, cDNA was in vitro transcribed and labelled with biotin using the IVT labelling kit (Affymetrix, Santa Clara, CA, USA) followed by the fragmentation of the biotinylated cRNA. The fragmented cRNA was hybridized overnight to the Affymetrix Human Genome (HG) U133 Plus 2.0 Array (Affymetrix). This array contains more than 54000 probe sets. Each probe set is designed to detect one specific gene or transcript. The microarray contains a redundant number of probe sets. A gene can be represented by 2 or even more than 10 probe sets. This means that about 54000 probe sets on the Affymetrix HG U133 Plus 2.0 Array cover the whole human genome of about 20 000-30 000 genes.

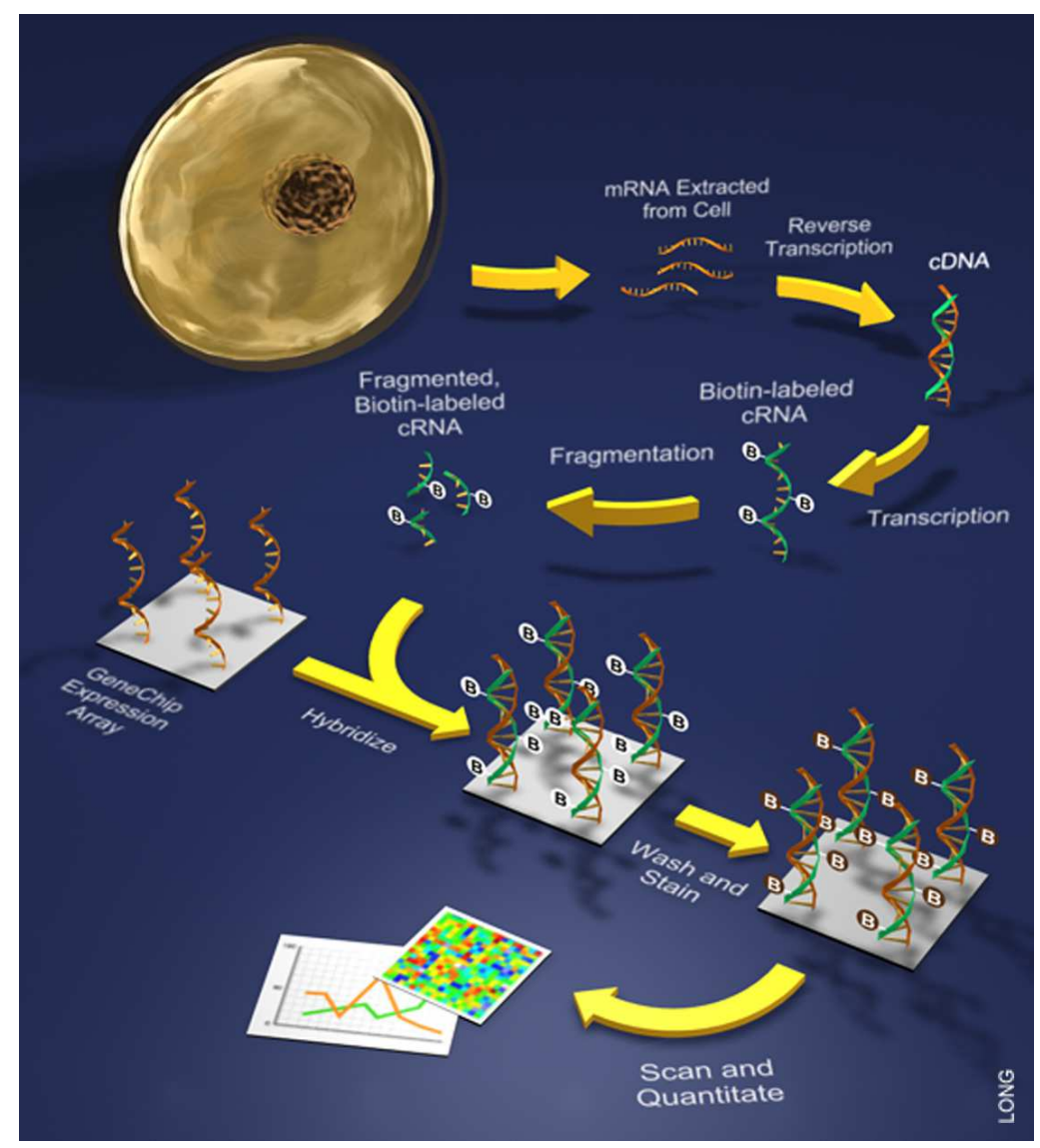

Fig. 2. Microarray work flow. Attributed to The Science Creative Quarterly (scq.ubc.ca). 


\subsection{Data analysis}

\subsubsection{Significant differential expression}

Affymetrix GeneChip Operating Software (GCOS) version 1.4 with the MAS 5.0 algorithm was used to analyse the resulting image files. Transcripts were considered as differentially expressed when the following criteria were met: (i) present $(\mathrm{P})$ 'calls' in all samples of the selected group; (ii) consistent (minimum in $2 / 3$ of the comparisons) decreased or increased change in expression for pair-wise comparisons between the two selected groups; (iii) a mean absolute value of the signal $\log$ ratio (SLR) $\geq 0.5$; this equals a fold change ratio (FC) of 1.4 or higher and (iv) a two-tailed unpaired Student's t-test with a significant result $(\mathrm{P} \leq$ 0.05). The data files have been deposited in $\mathrm{NCBI}^{\prime}$ s public database Gene Expression Omnibus (GEO) according to MIAME (Minimum Information About a Microarray Experiment) guidelines.

\subsubsection{PCA and clustering}

Principal component analysis (PCA) and hierarchical clustering was performed in an unsupervised way with GeneSpring GX software (Agilent Technologies). Principal component analysis is mainly used to visually assess the quality of replicate samples. Each point in the 3D plot represents a sample. With multiple replicates in each group, the replicates should be grouped together. If any of the biological replicates mix with another group, this sample may be further examined. PCA is a tool to visualize multidimensional data, like microarray data, into two or three dimensions. Each dimension represents a principal component (PC) with a certain percentage of variance. The percentage of variation is captured along three axes with the first axis (PCA 1) having the largest percentage of variation.

Hierarchical cluster analysis is a statistical method to group samples unsupervised in different clusters or branches of the hierarchical or condition tree. In this way, the relationships between the different groups are shown (Eisen et al., 1998). The condition tree can be displayed as a socalled 'heat map', based on the measured expression levels of the probe sets.

\subsubsection{Network and pathway analysis}

Further gene ontology study was performed with Ingenuity Pathways Analysis (IPA) software (Ingenuity® Systems, www.ingenuity.com, Redwood City, CA, USA) for further network and pathway analysis. A data file was uploaded that contained the gene identifiers for the differentially expressed probe sets and the corresponding expression values. Each gene identifier was mapped to its corresponding gene (object) in the Ingenuity Pathways Knowledge Base (IPKB). A log ratio threshold of 0.5 was set to identify focus genes whose expression was significantly differentially regulated. Networks of these genes were then algorithmically generated based on their connectivity in the IPKB. The networks were assigned a score, according to their relevance to the list of focus genes. Each network was arbitrarily set to have a maximum of 35 focus genes. Networks are shown as nodes and lines: nodes represent genes and lines represent the relationships between the genes (see Figure 4 in the Results section). All lines are supported by at least one reference from the literature. The intensity of the node colour indicates the degree of up- (red) or down- (green) regulation. Nodes are displayed using various shapes representing the functional class of the gene product (see legend Figure 4). 
The functional analysis identified the biological functions and/or diseases that were most significant to the data set (see Figure 5). Genes from the data set that met the P-value threshold of 0.05 (Fisher's exact test) and were associated with biological functions and/or diseases in the IPKB were considered for the analysis.

Canonical pathway analysis (see Figure 6) identified the pathways most significant to the data set, based on two parameters: (i) a ratio of the number of genes from the data set that map to the pathway divided by the total number of genes that map to the canonical pathway; (ii) Fisher's exact test was used to calculate a P-value determining the probability that the association between the genes in the dataset and the canonical pathway is explained by chance alone (www.ingenuity.com/company/pdf/Citation_Guidelines_2005-09-13.pdf).

\subsection{QPCR validation}

Quantitative validation was performed with QPCR for selected genes. Genes were selected for validation by quantitative real-time PCR (QPCR) because of their highly significant p-value or fold change ratio (FC) and/or because more than one probe set for the same gene was significantly differentially expressed. The selection also occurred on the available literature.

A two-step real-time PCR was performed. A reverse-transcription reaction from total RNA was achieved with the High-Capacity cDNA Archive kit (Applied Biosystems, Foster City, CA, USA) following the manufacturer's protocol. The quantitative real-time PCR was performed with the TaqMan Gene Expression Assay (Applied Biosystems), containing two unlabeled primers and one TaqMan FAM dye-labelled MGB ('minor groove binding') probe. Glyceraldehyde-3-phosphate dehydrogenase (GAPDH) was chosen as the control housekeeping gene using the TaqMan Endogenous Control Assay (Applied Biosystems) containing two unlabeled primers and one TaqMan FAM dye-labelled MGB probe. Both assays are cDNA specific, since the probes span an exon junction.

All real-time PCR assays were run using the TaqMan Universal PCR Master Mix plus AmpErase UNG (Applied Biosystems) on the 7900 HT Fast System (Applied Biosystems). Thermal cycling parameters were set as follows: $2 \mathrm{~min}$. at $50^{\circ} \mathrm{C}$ (AmpErase UNG activation), $10 \mathrm{~min}$. at $95^{\circ} \mathrm{C}$ (AmpliTaq Gold activation), followed by 40 cycles of denaturation, annealing and extension ( $15 \mathrm{sec}$. at $95^{\circ} \mathrm{C}$ and $1 \mathrm{~min}$. at $60^{\circ} \mathrm{C}$, respectively). No-template and no-RT (reverse transcriptase) controls were included to verify the quality and cDNA specificity of the primers. All samples were analysed in triplicate. The relative quantification was performed by the standard curve method. For each sample, the amount of target gene and endogenous control (GAPDH) was determined from their respective standard curves. First, the target gene amount was divided by the endogenous control amount to obtain a normalized value. In a second step, the samples were normalized again to the sample with the lowest normalized expression, the calibrator sample or $1 x$ sample. Therefore, each of the normalized values was divided by the calibrator normalized value to generate the relative expression levels. Significance was achieved when $\mathrm{p}<0.05$ (with t-test).

\section{Results}

\subsection{Patient groups}

The endometrial gene expression profile on the day of oocyte retrieval in rec-FSH stimulated GnRH-antagonist cycles for IVF with embryo transfer in the same cycle was studied and 
correlated with the serum $\mathrm{P}$ concentration on the day of hCG administration (Van Vaerenbergh et al., 2011). Three groups of patients ( $n=14$ in total) with different serum $P$ concentrations on the day of hCG were analysed: a group with P below $0.9 \mathrm{ng} / \mathrm{ml}$, an intermediate group with $P$ from 1 to $1.5 \mathrm{ng} / \mathrm{ml}$ and a high concentration group with $\mathrm{P}$ above $1.5 \mathrm{ng} / \mathrm{ml}$. These cut-offs were based on the recent literature (Papanikolaou et al., 2009; Venetis et al., 2007). In these articles, $0.9 \mathrm{ng} / \mathrm{ml}$ was found as the lowest threshold for $\mathrm{P}$ concentration and $1.5 \mathrm{ng} / \mathrm{ml}$ was found as the highest threshold. Although different cut-offs have been used over the years ranging from 0.8 to even $2 \mathrm{ng} / \mathrm{ml}$ (Hofmann et al., 1993; Ubaldi et al., 1996; Silverberg et al., 1994; Edelstein et al., 1990; Givens et al., 1994), in recent publications the upper cut-off level is set at $1.5 \mathrm{ng} / \mathrm{ml}$.

In these three groups of patients, the patients with a clinical pregnancy (defined according to ICMART/WHO terminology, as a pregnancy diagnosed by ultrasonographic visualization of one or more gestational sacs or definitive clinical signs of pregnancy; Zegers-Hochschild et al., 2009) were observed in the low and intermediate group. No clinical pregnancies occurred when the P concentration on the day of hCG administration was above $1.5 \mathrm{ng} / \mathrm{ml}$.

Histological dating demonstrated an advanced secretory endometrial maturation for the majority of patients (13 out of 14 or $92.8 \%$ ), ranging from +day 2 (two days advanced as compared to the chronological cycle day, which is the day of oocyte retrieval, considered as day 0) to +day 4 .

\subsection{Gene expression}

In the comparison between 3 groups, a small difference in gene expression between the first two groups was found. However, the gene expression profile from patients with high $\mathrm{P}$ concentration $(>1.5 \mathrm{ng} / \mathrm{ml})$ was significantly different from the patients in the other two groups. These results were also confirmed with principal component analysis and hierarchical clustering, where a separate cluster for patients with high $\mathrm{P}$ concentration $(>1.5$ $\mathrm{ng} / \mathrm{ml}$ ) was found (Figure $3 \mathrm{a}$ and $3 \mathrm{~b}$ ). In this way, the threshold of $1.5 \mathrm{ng} / \mathrm{ml}$, as suggested in recent literature (Papanikolaou et al., 2009; Bosch et al., 2010), was confirmed at the molecular level.

\subsection{Validation with QPCR}

The results obtained with the microarray gene expression analysis have been validated for selected genes with a more quantitative real-time PCR technique. Some of the genes that were selected for validation had already known roles in the reproductive system. For example DKK3 (Dickkopf homolog 3) is a known molecule in the Wnt/ $\beta$ catenin signalling pathway. Other genes that were selected for validation with QPCR were: PAPPA (pregnancy associated plasma protein A or pappalysin), PRSS23 (protease serine 23), IL17RB (interleukin 17 receptor B), and THSD4 (thrombospondin type 1 domain containing 4).

These genes all showed a significant fold change (compared between the intermediate $\mathrm{P}$ concentration group and the high concentration group) comparable with their fold changes obtained in the microarray experiment. 


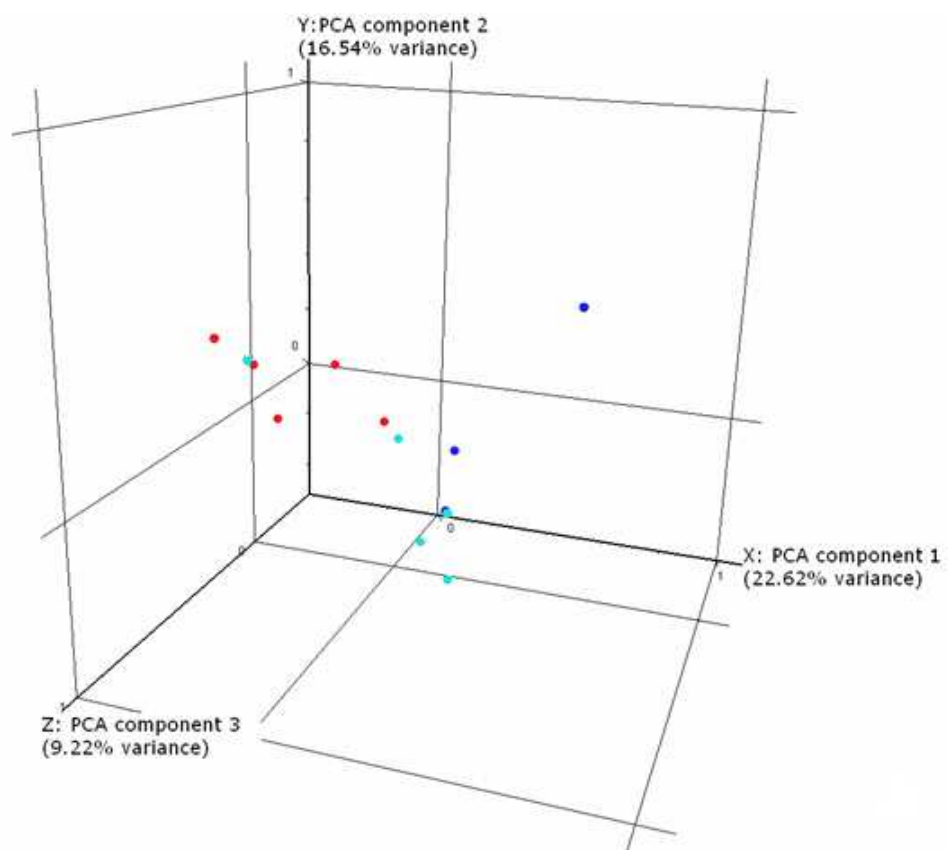

Fig. 3a. Principal component analysis (PCA) of 14 endometrial biopsies of patients with premature P rise on the day of hCG administration: low P concentration group (dark blue), an intermediate $\mathrm{P}$ concentration group (light blue) and high $\mathrm{P}$ concentration group (red).

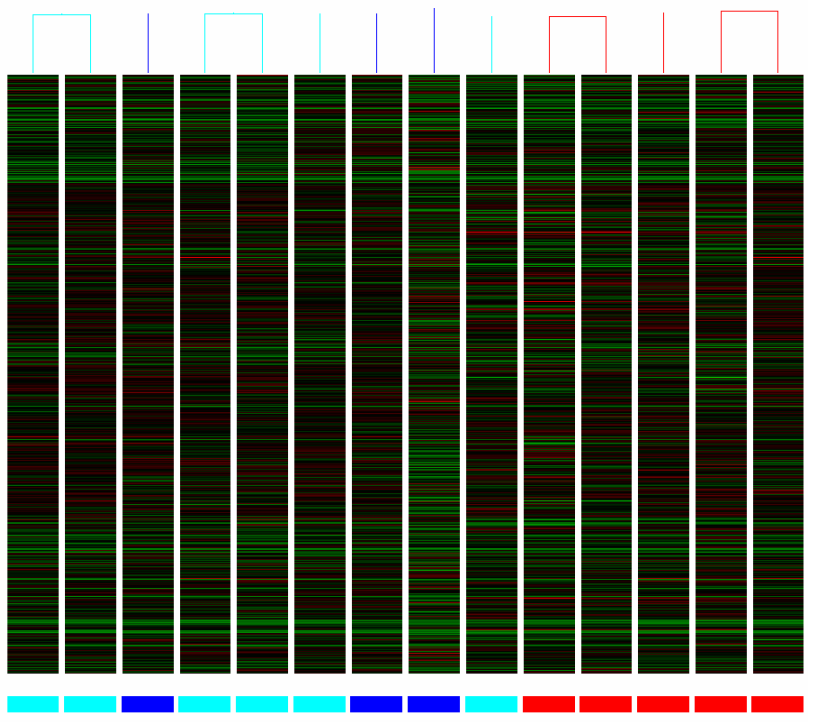

Fig. 3b. Hierarchical clustering analysis (condition tree) of the 14 endometrial samples, displayed as a heat map. Colour code: see legend figure $3 a$. 


\subsection{Pathway and network analysis}

The list of significantly differentially expressed probe sets (or genes) was further studied with Ingenuity to find the associated canonical pathways and to discover networks between the genes that can be formed based on the available literature. Biological functions that were most significant to the dataset were assigned. In total, 41 networks were derived from the gene list, from which 30 were made up of at least 13 focus molecules (Figure 4).

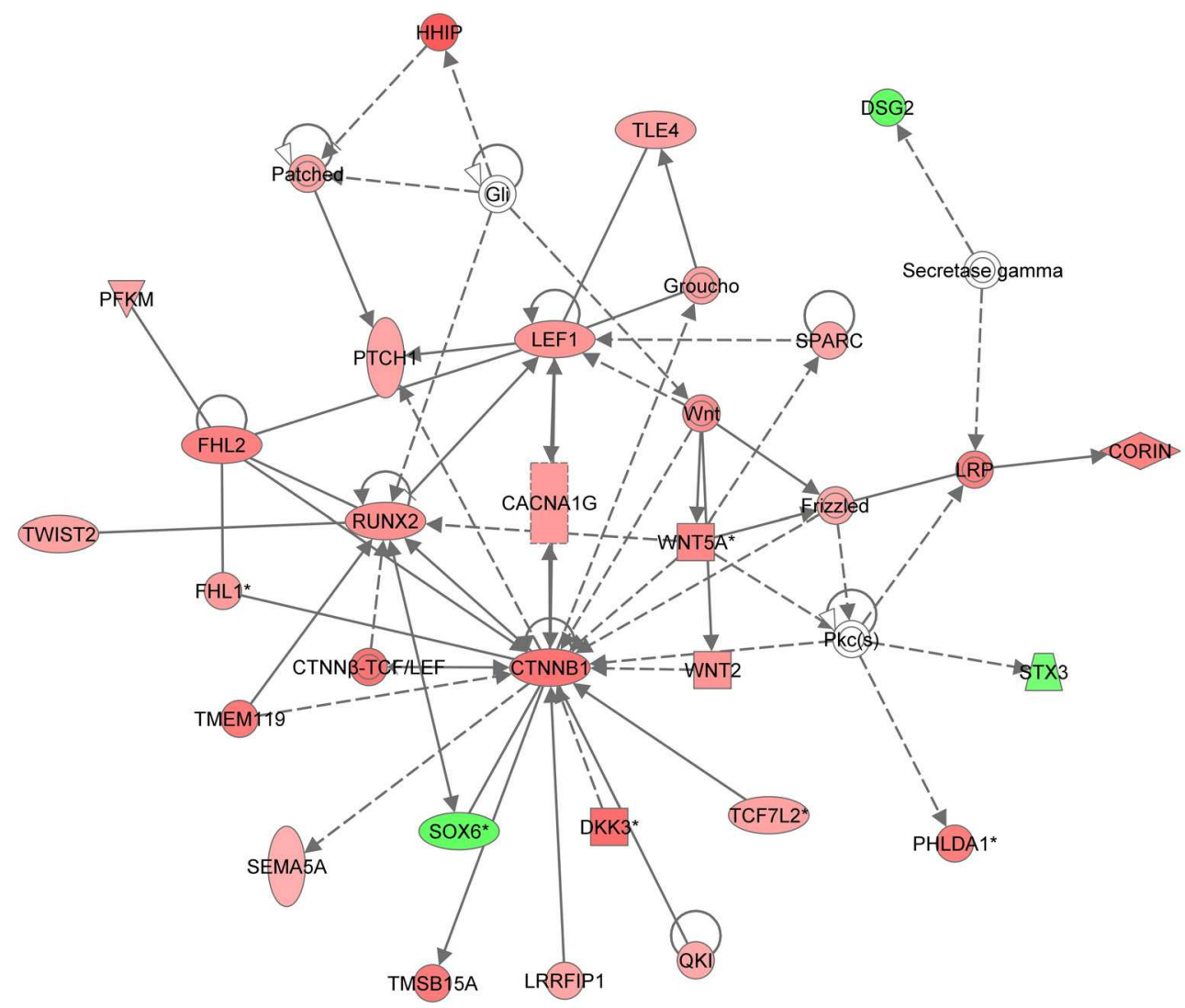

Fig. 4. Network formed on the basis of the literature findings in the Ingenuity database. Upregulated genes from our dataset are coloured red, downregulated genes are coloured green. The shape of the nodes represents the type of molecule (for example enzyme, transcription regulator, group or complex). The lines represent the relationships between the genes (direct or indirect interaction).

The functional analysis identified the biological functions that were most significant to the data set. The top functions were cancer, cellular growth and proliferation, genetic disorders, cellular movement and development and reproductive system diseases (Figure 5). 


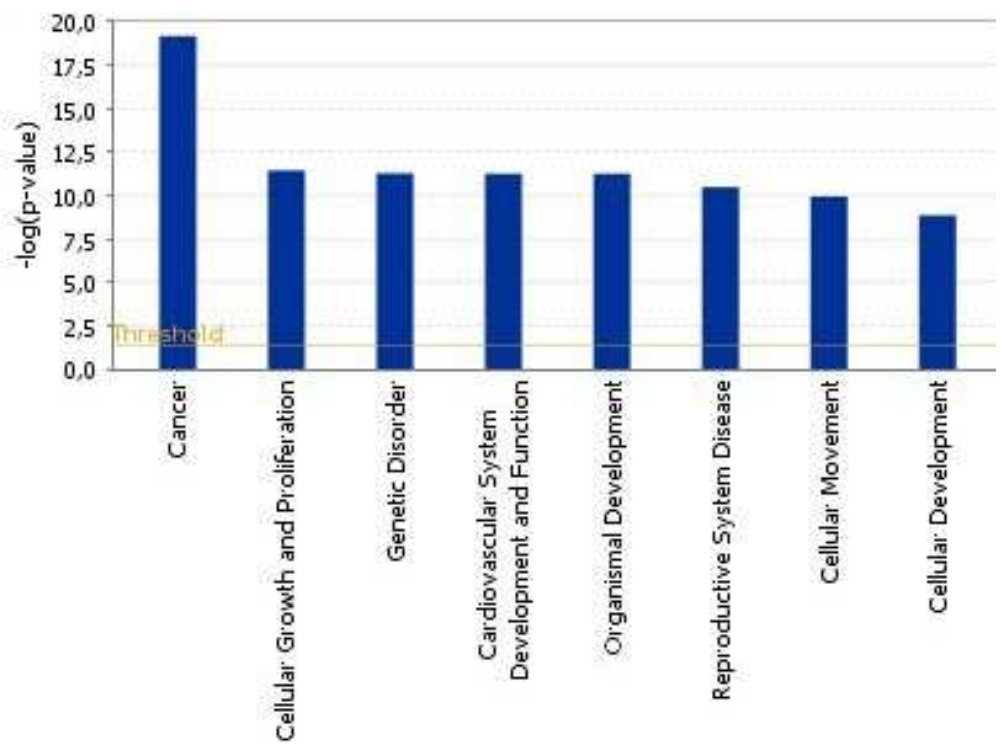

Fig. 5. Overview of the most relevant biological functions or diseases.

Pathway analysis was performed as well (Figure 6). A significant canonical pathway associated with both SOX family members and DKK family members from our data set was the Wnt/ $\beta$ catenin signalling pathway (Figure 7). This pathway is well known for its role in the reproductive system.

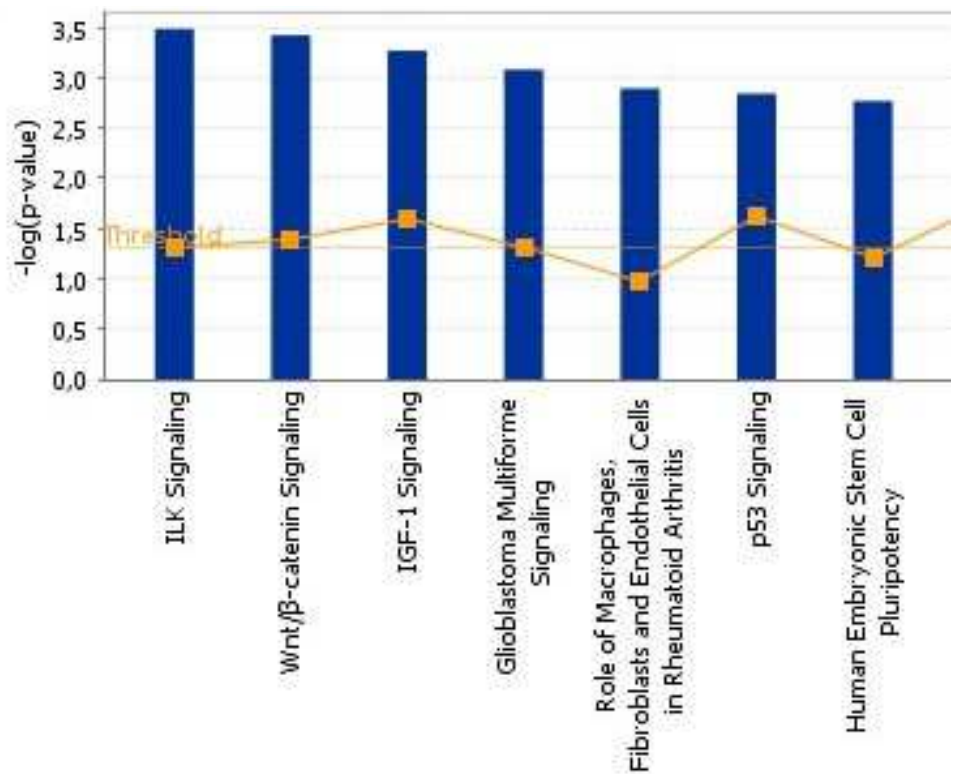

Fig. 6. Overview of the most relevant canonical pathways associated with the data set. 


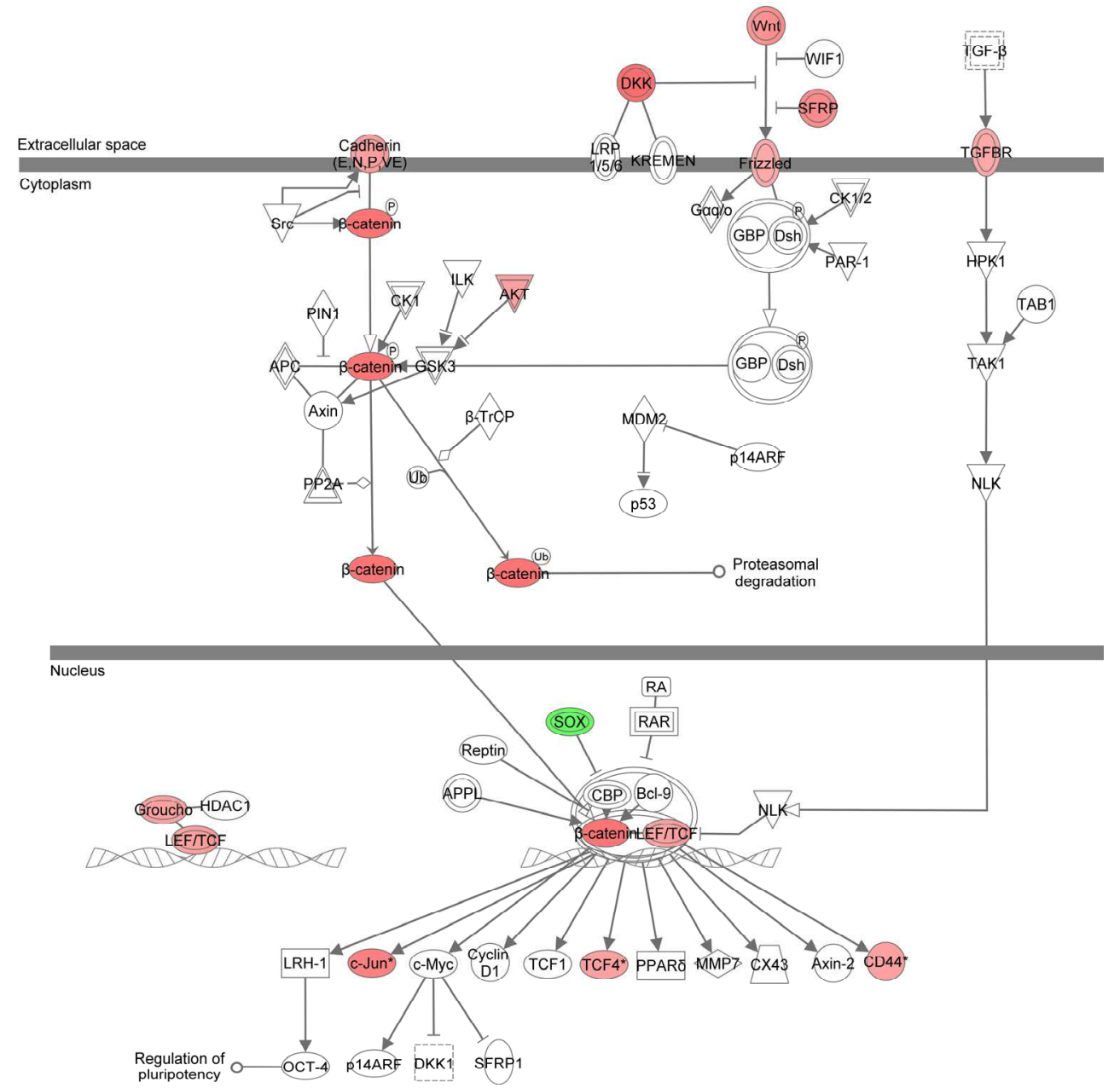

Fig. 7. Wnt/ $\beta$ catenin signalling pathway, in which the DKK (Dickkopf) molecules are upregulated (coloured red) and the SOX family members are downregulated (coloured green), according to our data set.

\section{Discussion}

Some patients undergoing a stimulated IVF protocol experience premature progesterone elevation towards the end of the follicular phase. Currently, there is an ongoing debate (Van Vaerenbergh et al., 2011 Hum Rep; Al-Azemi et al., submitted to Hum Rep Update) about the aetiology of this premature progesterone rise. It is hypothesized this is due to the high response of the ovary to the stimulation protocol and is associated with lower clinical pregnancy rates (Kyrou et al., 2009: Papanikolaou et al., 2009). In other recent studies, the effect of higher progesterone levels on the endometrial receptivity has been studied as well on the RNA level (Labarta et al., 2011), and even on the microRNA level (Li et al., 2011). 
In our study, several groups of patients with premature P rise were compared according to their serum P concentration on the day of hCG administration and in relationship with their gene expression profile on the day of oocyte retrieval. Several genes were selected out of the list of genes which were significantly differentially regulated between the groups with $1 \leq \mathrm{P}$ $\leq 1.5 \mathrm{ng} / \mathrm{ml}$ and $\mathrm{P}>1.5 \mathrm{ng} / \mathrm{ml}$ and confirmed with quantitative real-time PCR. The selection of genes occurred according to the criteria described above.

Some of the selected genes were already known for their role(s) in reproductive processes.

During each menstrual cycle, an extensive tissue remodelling process takes place. In the mammalian ovary, proteases are also required for remodelling of the extracellular matrix during follicular growth, breakdown of the follicular wall during ovulation, luteal formation and regression (Curry and Osteen, 2003; Ny et al., 2002). Up to date, several proteases have been implicated in the degradation of the extracellular matrix in the ovary as well as in the endometrium, such as MMPs (matrix metalloproteinases)/TIMPs (Tissue Inhibitor of Metalloproteinases) and ADAMTSs (A Disintegrin And Metalloproteinase with Thrombospondin Motifs).

Protease, serine 23 or PRSS23 is an extracellular serine protease expressed in the mouse ovary and may play a role in follicular development in the mouse. PRSS23 is highly expressed in atretic follicles and in the ovarian stroma and thecal layers just before ovulation. Its dynamic expression pattern suggests that PRSS23 is involved in different tissue remodelling processes in the ovary, possibly by allowing extracellular matrix degradation and/or regulating growth factor availability (Miyakoshi et al., 2006; Wahlberg et al., 2008).

THSD4 (thrombospondin, type I, domain containing 4) is an ADAMTS-like protein and has been described in human endometrium in a stimulated cycle in another study performed in the Centre for Reproductive Medicine (Blockeel et al., 2011).

The interleukin 17 receptor B (IL17RB or IL17BR) is an estrogen-regulated gene (Wang et al., 2007) and found to be a prognostic marker, together with homeobox 13 expression, for breast cancer (Jerevall et al., 2008; Ma et al., 2008). In general, interleukins, chemokines, cytokines and other immunological molecules are known to play a major role during implantation. (Lindhard et al., 2002).

Another protease is PAPP-A or IGFBP4 (insulin-like growth factor-binding protein-4), a metalloproteinase from the metzincin superfamily (Boldt and Conover, 2007; Conover et al., 2004; Ohnishi et al., 2005; Overgaard et al., 1999). This family also includes the astacins, serralysins, adamalysins (ADAMTS) and the matrix metalloproteinases (MMP) (HuxleyJones et al., 2007; Reiss et al., 2006). PAPP-A acts as a protease for IGFBP4 and in this way helps releasing IGF (insulin-like growth factor). IGF-II has a major role in implantation and trophoblast invasion (Giudice et al., 2002). Insuline-like growth factors can bind to six IGFbinding proteins, IGFBP1-6, which are able to modulate IGF actions in various ways (Suzuki et al., 2006). PAPP-A is produced by the trophoblasts and also known as a sensitive marker for adverse pregnancy outcome in the first trimester (Suzuki et al., 2006). Human decidualized endometrial stromal cells secrete PAPP-A as well (Giudice et al., 2002).

The Wnt/ $\beta$-catenin signalling pathway has been described before in different implantationrelated and endometrial receptivity studies (Tulac et al., 2003; Van Vaerenbergh et al., 2009). 
Furthermore, another member of the Dickkopf family, DKK1, has been observed in the midsecretory phase $(\mathrm{LH}+7)$ of a natural cycle in several endometrial receptivity gene expression studies (Carson et al., 2002; Haouzi et al., 2009; Riesewijk et al., 2003; Talbi et al., 2006).

Previous studies (Kolibianakis et al., 2002; Ubaldi et al., 1997) with endometrial biopsies on the day of oocyte retrieval and following embryo transfer demonstrated that an endometrial advancement of more than 3 days never resulted in a clinical pregnancy. From an earlier study in our group (Van Vaerenbergh et al., 2009), these findings were confirmed on the gene expression level with microarrays. It was found that endometrial samples taken on the day of oocyte retrieval from patients in a GnRH antagonist/ rec-FSH stimulation protocol for IVF with embryo transfer all showed an advanced endometrial maturation and that the samples with an advanced endometrium of more than 3 days clustered together in a separate molecular profile.

In this study, no clinical pregnancies were seen when the P concentration was higher than $1.5 \mathrm{ng} / \mathrm{ml}$. All four clinical pregnancies ensued in patients from groups with $\mathrm{P} \leq 0.9 \mathrm{ng} / \mathrm{ml}$ and with $1 \leq \mathrm{P} \leq 1.5 \mathrm{ng} / \mathrm{ml}$.

A large group of significantly differentially expressed probe sets was observed between the group with progesterone levels between 1 and $1.5 \mathrm{ng} / \mathrm{ml}(1 \leq \mathrm{P} \leq 1.5 \mathrm{ng} / \mathrm{ml})$ and the group with progesterone levels above $1.5 \mathrm{ng} / \mathrm{ml}$. Moreover, hierarchical clustering analysis and principal component analysis showed a separate cluster for patients in the group with progesterone concentrations above $1.5 \mathrm{ng} / \mathrm{ml}$. The clustering pattern possibly also reflects the state of endometrial maturation of the biopsy, as one sample dated as +day 4 , is more closely situated near the cluster from the group with the highest progesterone concentrations. Although, there is a trend noticeable that patients with premature progesterone rise on the day of hCG administration have a morphological advanced secretory endometrium, this is not always true. In the current study, it can be demonstrated from the clustering analyses and the available histological dating results that the elevation of progesterone levels in the follicular phase seems somehow related to the endometrial maturation state, although predicting the histological date of the endometrial biopsy is not possible.

\section{Conclusion}

This is the first study to investigate the endometrial gene expression on the day of oocyte retrieval in stimulated cycles for IVF with embryo transfer, according to the concentration of progesterone on the day of hCG administration.

In conclusion, the early elevation of progesterone on the day of hCG administration seems to have an instant effect on the endometrial gene expression, as shown by a biopsy sample taken only 36 hours later, on the day of oocyte retrieval. The threshold for P concentration with a distinct different molecular profile was found at $1.5 \mathrm{ng} / \mathrm{ml}$.

These significant changes observed at the gene expression level may explain the impairment of endometrial receptivity in the presence of elevated progesterone, reflected in the lower clinical pregnancy rates as reported in recent publications (Bosch et al., 2003; 2010; Kolibianakis et al., 2011). 


\section{Acknowledgment}

This study was originally published in Reproductive Biomedicine Online (Van Vaerenbergh et al., 2011).

Furthermore, we would like to thank the Fonds Wetenschappelijk Onderzoek - Vlaanderen (FWO) for its financial support with grant G031707N (FWO AL405) during this study.

\section{References}

Al-Azemi M, Kyrou D, Kolibianakis EM, Humaidan P, Van Vaerenbergh I, Devroey P, Fatemi HM. Elevated Progesterone during Ovarian Stimulation for In-Vitro Fertilization. SUBMITTED

Blockeel C, Van Vaerenbergh I, Fatemi HM, Van Lommel L, Devroey P, Bourgain C. Gene expression profile in the endometrium on the day of oocyte retrieval after ovarian stimulation with low-dose hCG in the follicular phase. Mol Hum Reprod, 2011;17(1):33-41.

Boldt HB, Conover CA. Pregnancy-associated plasma protein-A (PAPP-A): a local regulator of IGF bioavailability through cleavage of IGFBPs. Growth Horm IGF Res, 2007;17(1):10-8.

Bosch E, Valencia I, Escudero E, Crespo J, Simon C, Remohi J, Pellicer A. Premature luteinisation during gonadotropin-releasing hormone antagonist cycles and its relationship with in vitro fertilization outcome. Fertil Steril, 2003;80(6):1444-9.

Bosch E, Labarta E, Crespo J, Simon C, Remohi J, Jenkins J, Pellicer A. Circulating progesterone levels and ongoing pregnancy rates in controlled ovarian stimulation cycles for in vitro fertilization: analysis of over 4000 cycles. Hum Reprod, 2010;25(8):2092-100.

Carson DD, Lagow E, Thathiah A, Al-Shami R, Farach-Carson MC, Vernon M, Yuan L, Fritz MA, Lessey B. Changes in gene expression during the early to mid-luteal (receptive phase) transition in human endometrium detected by high-density microarray screening. Mol Hum Reprod, 2002;8(9):871-9.

Conover CA, Bale LK, Overgaard MT, Johnstone EW, Laursen UH, Füchtbauer EM, Oxvig C, van Deursen J. Metalloproteinase pregnancy-associated plasma protein A is a criticalgrowth regulatory factor during fetal development. Development, 2004;131(5):1187-94.

Curry TE Jr, Osteen KG. The matrix metalloproteinase system: changes, regulation, and impact throughout the ovarian and uterine reproductive cycle. Endocr Rev, 2003;24(4):428-465.

Edelstein MC, Seltman HJ, Cox BJ, Robinson SM, Shaw RA, Muasher SJ. Progesterone levels on the day of human chorionic gonadotropin administration in cycles with gonadotropin-releasing hormone agonist suppression are not predictive of pregnancy outcome. Fertil Steril 1990;54:853-857.

Eisen MB, Spellman PT, Brown PO, Botstein D. Cluster analysis and display of genomewide expression patterns. Proc Natl Acad Sci USA, 1998;95(25):14863-14868.

Giudice LC, Conover CA, Bale L, Faessen GH, Ilg K, Sun I, Imani B, Suen LF, Irwin JC, Christiansen M, Overgaard MT, Oxvig C. Identification and regulation of the IGFBP-4 protease and its physiological inhibitor in human trophoblasts and 
endometrial stroma: evidence for paracrine regulation of IGF-II bioavailability in the placental bed during human implantation. J Clin Endocrinol Metab, 2002;87(5):2359-2366.

Givens CR, Schriock ED, Dandekar PV, Martin MC. Elevated serum progesterone levels on the day of human chorionic gonadotropin administration do not predict outcome in assisted reproduction cycles. Fertil Steril 1994; 62:1011-1017.

Haouzi D, Mahmoud K, Fourar M, Bendhaou K, Dechaud H, De Vos J, Rème T, Dewailly D, Hamamah S. Identification of new biomarkers of human endometrial receptivity in the natural cycle. Hum Reprod. 2009 ;24(1):198-205.

Hofmann GE, Bentzien F, Bergh PA, Garrisi GJ, Williams MC, Guzman I, Navot D. Premature luteinization in controlled ovarian hyperstimulation has no adverse effect on oocyte and embryo quality. Fertil Steril, 1993;60(4):675-9.

Huxley-Jones J, Clarke TK, Beck C, Toubaris G, Robertson DL, Boot-Handford RP. The evolution of the vertebrate metzincins; insights from Ciona intestinalis and Danio rerio. BMC Evol Biol, 2007;17(7):63.

Jerevall PL, Brommesson S, Strand C, Gruvberger-Saal S, Malmström P, Nordenskjöld B, Wingren S, Söderkvist P, Fernö M, Stål O. Exploring the two-gene ratio in breast cancer-independent roles for HOXB13 and IL17BR in prediction of clinical outcome. Breast Cancer Res Treat, 2008;107(2):225-34.

Kolibianakis EM, Venetis CA, Bontis J, Tarlatzis BC. Significantly Lower Pregnancy Rates in the Presence of Progesterone Elevation in Patients Treated with GnRH Antagonists and Gonadotrophins: A Systematic Review and Meta-Analysis. Curr Pharm Biotechnol. 2011 Jun 9. [Epub ahead of print]

Kolibianakis E, Bourgain C, Albano C, Osmanagaoglu K, Smitz J, Van Steirteghem A, Devroey P. Effect of ovarian stimulation with recombinant follicle-stimulating hormone, gonadotropin releasing hormone antagonists, and human chorionic gonadotropin on endometrial maturation on the day of oocyte pick-up. Fertil Steril, 2002;78(5):1025-1029.

Kyrou D, Popovic-Todorovic B, Fatemi HM, Bourgain C, Haentjens P, Van Landuyt L, Devroey P. Does the estradiol level on the day of human chorionic gonadotrophin administration have an impact on pregnancy rates in patients treated with recFSH/GnRH antagonist? Hum Reprod, 2009;24(11):2902-9.

Labarta E, Martínez-Conejero JA, Alamá P, Horcajadas JA, Pellicer A, Simón C, Bosch E. Endometrial receptivity is affected in women with high circulating progesterone levels at the end of the follicular phase: a functional genomics analysis. Hum Reprod. 2011 Jul;26(7):1813-25.

Lindhard A, Bentin-Ley U, Ravn V, Islin H, Hviid T, Rex S, Bangsbøll S, Sørensen S. Biochemical evaluation of endometrial function at the time of implantation. Fertil Steril 2002;78(2):221-33.

Li R, Qiao J, Wang L, Li L, Zhen X, Liu P, Zheng X. MicroRNA array and microarray evaluation of endometrial receptivity in patients with high serum progesterone levels on the day of hCG administration. Reproductive Biology and Endocrinology 2011, 9:29

Ma XJ, Salunga R, Dahiya S, Wang W, Carney E, Durbecq V, Harris A, Goss P, Sotiriou C, Erlander M, Sgroi D. A five-gene molecular grade index and HOXB13:IL17BR are 
complementary prognostic factors in early stage breast cancer. Clin Cancer Res, 2008;14(9):2601-8.

Miyakoshi K, Murphy MJ, Yeoman RR, Mitra S, Dubay CJ, Hennebold JD. The identification of novel ovarian proteases through the use of genomic and bioinformatics methodologies. Biol Reprod, 2006;75(6):823-835.

Noyes RW, Hertig AT, Rock J. Dating the endometrial biopsy. Fertil Steril, 1950;1:3-25.

Ny T, Wahlberg P, Brändström IJ. Matrix remodeling in the ovary: regulation and functional role of the plasminogen activator and matrix metalloproteinase systems. Mol Cell Endocrinol, 2002;187(1-2):29-38.

Ohnishi J, Ohnishi E, Shibuya H, Takahashi T. Functions for proteinases in the ovulatory process. Biochimica et Biophysica Acta, 2005;1751(1):95-109.

Overgaard MT, Oxvig C, Christiansen M, Lawrence JB, Conover CA, Gleich GJ, SottrupJensen L, Haaning J. Messenger ribonucleic acid levels of pregnancy associated plasma protein-A and the proform of eosinophil major basic protein: expression in human reproductive and nonreproductive tissues. Biol Reprod, 1999;61(4):10831089.

Papanikolaou EG, Kolibianakis EM, Pozzobon C, Tank P, Tournaye H, Bourgain C, Van Steirteghem A, Devroey P. Progesterone rise on the day of human chorionic gonadotropin administration impairs pregnancy outcome in day 3 single-embryo transfer, while has no effect on day 5 single blastocyst transfer. Fertil Steril, 2009;91(3):949-952.

Reiss K, Ludwig A, Saftig P. Breaking up the tie: disintegrin-like metalloproteinases as regulators of cell migration in inflammation and invasion. Pharmacol Ther, 2006;111(3):985-1006.

Riesewijk A, Martín J, van Os R, Horcajadas JA, Polman J, Pellicer A, Mosselman S, Simon C. Gene expression profiling of human endometrial receptivity on days $\mathrm{LH}+2$ versus LH+7 by microarray technology. Mol Hum Reprod, 2003;9(5):253-64.

Rotterdam ESHRE/ASRM-Sponsored PCOS Consensus Workshop Group. Revised 2003 consensus on diagnostic criteria and long-term health risks related to polycystic ovary syndrome. Fertil Steril, 2004;81(1):19-25.

Silverberg KM, Burns WN, Olive DL, Riehl RM, Schenken RS. Serum progesterone levels predict success of in vitro fertilization/embryo transfer in patients stimulated with leuprolide acetate and human menopausal gonadotropins. J Clin Endocrinol Metab 1991;73:797-803.

Silverberg KM, Martin M, Olive DL, Burns WN, Schenken RS. Elevated serum progesterone levels on the day of human chorionic gonadotropin administration in in vitro fertilization cycles do not adversely affect embryo quality. Fertil Steril 1994;61:508513.

Suzuki K, Sata F, Yamada H, Saijo Y, Tsuruga N, Minakami H, Kishi R. Pregnancyassociated plasma protein-A polymorphism and the risk of recurrent pregnancy loss. J Reprod Immunol, 2006;70(1-2):99-108.

Talbi S, Hamilton AE, Vo KC, Tulac S, Overgaard MT, Dosiou C, Le Shay N, Nezhat CN, Kempson R, Lessey BA, Nayak NR, Giudice LC. Molecular phenotyping of human endometrium distinguishes menstrual cycle phases and underlying biological processes in normo-ovulatory women. Endocrinology, 2006;147(3):1097-121. 
Tulac S, Nayak NR, Kao LC, Van Waes M, Huang J, Lobo S, Germeyer A, Lessey BA, Taylor $\mathrm{RN}$, Suchanek E, Giudice LC. Identification, characterization, and regulation of the canonical Wnt signaling pathway in human endometrium. J Clin Endocrinol Metab, 2003;88(8):3860-3866.

Ubaldi F, Albano C, Peukert M, Riethmuller-Winzen H, Camus M, Smitz J, Van Steirteghem A, Devroey P. Subtle progesterone rise after administration of the gonadotrophinreleasing hormone antagonist cetrorelix in intracytoplasmic sperm injection cycles. Hum Reprod 1996;11:1405-1407.

Ubaldi F, Bourgain C, Tournaye H, Smitz J, Van Steirteghem A, Devroey P. Endometrial evaluation by aspiration biopsy on the day of oocyte retrieval in the embryo transfer cycles in patients with serum progesterone rise during the follicular phase. Fertil Steril, 1997;67(3):521-526.

Van Landuyt L, De Vos A, Joris H, Verheyen G, Devroey P, Van Steirteghem A. Blastocyst formation in in vitro fertilization versus intracytoplasmic sperm injection cycles: influence of the fertilization procedure. Fertil Steril 2005;83:1397-1403.

Van Vaerenbergh I, Fatemi HM, Blockeel C, Van Lommel L, In't Veld P, Schuit F, Kolibianakis EM, Devroey P, Bourgain C. Progesterone rise on hCG day in GnRH antagonist/rec-FSH stimulated cycles affects endometrial gene expression. RBM Online, 2011;22(3):263-271.

Van Vaerenbergh I, Fatemi HM and Bourgain C. Premature progesterone rise and gene expression. Hum Reprod. 2011 Oct;26(10):2913.

Van Vaerenbergh I, Van Lommel L, Ghislain V, In't Veld P, Schuit F, Fatemi HM, Devroey P, Bourgain C. In GnRH antagonist/rec-FSH stimulated cycles, advanced endometrial maturation on the day of oocyte retrieval correlates with altered gene expression. Hum Reprod, 2009;24(5):1085-1091.

Venetis CA, Kolibianakis EM, Papanikolaou E, Bontis J, Devroey P, Tarlatzis BC. Is progesterone elevation on the day of human chorionic gonadotrophin administration associated with the propability of pregnancy in in vitro fertilization? A systematic review and meta-analysis. Hum Reprod Update, 2007;13(4):343-355.

Wahlberg P, Nylander A, Ahlskog N, Liu K, Ny T. Expression and localization of the serine proteases high-temperature requirement factor $\mathrm{A} 1$, serine protease 23 , and serine protease 35 in the mouse ovary. Endocrinology, 2008;149(10):5070-5077.

Wang H, Xie H, Sun X, Tranguch S, Zhang H, Jia X, Wang D, Das SK, Desvergne B, Wahli W, DuBois RN, Dey SK. Stage-specific integration of maternal and embryonic PPARdelta signaling is critical to pregnancy success. J Biol Chem, 2007;282(52):37770-82.

Zegers-Hochschild F, Adamson GD, de Mouzon J, Ishihara O, Mansour R, Nygren K, Sullivan E, van der Poel S; International Committee for Monitoring Assisted Reproductive Technology; World Health Organization. The International Committee for Monitoring Assisted Reproductive Technology (ICMART) and the World Health Organization (WHO) Revised Glossary on ART Terminology, 2009. Hum Reprod 2009;24(11):2683-2687. 


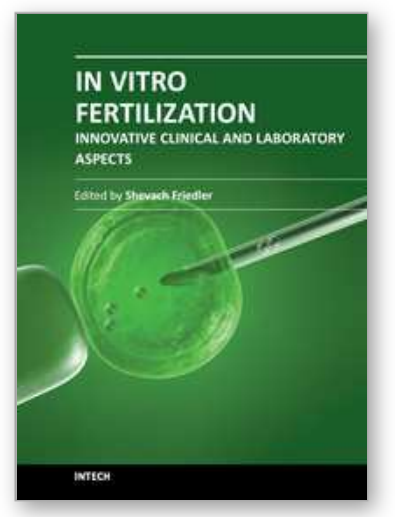

\author{
In Vitro Fertilization - Innovative Clinical and Laboratory Aspects \\ Edited by Prof. Shevach Friedler
}

ISBN 978-953-51-0503-9

Hard cover, 156 pages

Publisher InTech

Published online 11, April, 2012

Published in print edition April, 2012

The field of In Vitro Fertilization is a relatively new field in medicine, constantly on the move. This field is an exquisite example of the vast power in the complementary use of basic research with clinical practice and opened a new route of great basic and clinical research possibilities. The knowledge base that allowed the accomplishment of the idea of in vitro fertilization and embryo transfer has much developed since. The vast body of research pertaining to this field allowed deepening our understanding in the processes related to reproduction. In this book on in vitro fertilization we present new and interesting updated information in various aspects of this field. This work is a result of collaborative work of an international group of professionals dedicated to contribute to the advancement of our knowledge.

\title{
How to reference
}

In order to correctly reference this scholarly work, feel free to copy and paste the following:

Inge Van Vaerenbergh and Christophe Blockeel (2012). Gene Expression and Premature Progesterone Rise, In Vitro Fertilization - Innovative Clinical and Laboratory Aspects, Prof. Shevach Friedler (Ed.), ISBN: 978-95351-0503-9, InTech, Available from: http://www.intechopen.com/books/in-vitro-fertilization-innovative-clinicaland-laboratory-aspects/gene-expression-and-premature-progesterone-rise

\section{INTECH}

open science | open minds

\section{InTech Europe}

University Campus STeP Ri

Slavka Krautzeka 83/A

51000 Rijeka, Croatia

Phone: +385 (51) 770447

Fax: +385 (51) 686166

www.intechopen.com

\section{InTech China}

Unit 405, Office Block, Hotel Equatorial Shanghai

No.65, Yan An Road (West), Shanghai, 200040, China

中国上海市延安西路65号上海国际贵都大饭店办公楼 405 单元

Phone: +86-21-62489820

Fax: $+86-21-62489821$ 
(C) 2012 The Author(s). Licensee IntechOpen. This is an open access article distributed under the terms of the Creative Commons Attribution 3.0 License, which permits unrestricted use, distribution, and reproduction in any medium, provided the original work is properly cited. 